\title{
Clinical Applications of Botulinum Toxin in Oral and Maxillofacial Surgery
}

\author{
Ahmed Wallan Al Ahmary ${ }^{1}$, Sabrin Moshabab Alqhtani ${ }^{1}$, Bshayer Abdullah Alshahrani ${ }^{1}$, Wadiah Abdullah Alkaram ${ }^{1}$, \\ Bayan Saeed Alhadad ${ }^{1}$, Ahmed M. Elmarakby ${ }^{2,3 *}$ \\ ${ }^{1}$ Department of Oral and Maxillofacial Surgery, Al-Farabi Colleges for Dentistry and Nursing, Riyadh, Saudi Arabia; ${ }^{2}$ Department \\ of Restorative Dental Sciences, Al-Farabi Colleges for Dentistry and Nursing, Riyadh, Saudi Arabia; ${ }^{3}$ Department Operative \\ Dentistry, Faculty of Dental Medicine, Al-Azhar University, Assiut Branch, Egypt
}

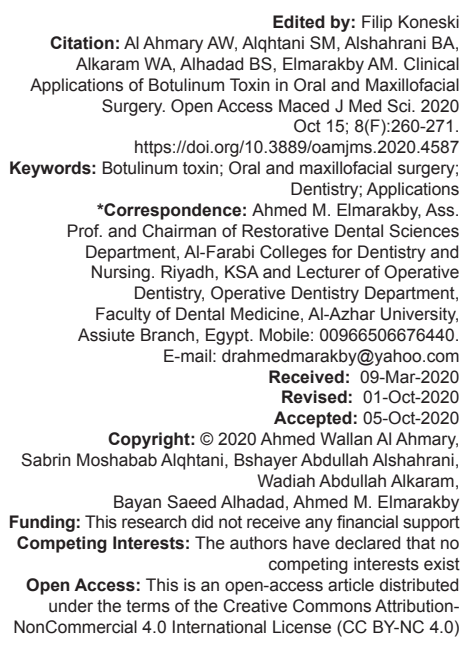
Edited by: Filip Koneski
Citation: Al Ahmary AW, Alqhtani SM, Alshahrani BA, Alk: A AhA Alhadad BS, El SM, Alshahrani BA, plications of Botulinum Toxin in Oral and Maxillofacia Surgery. Open Access Maced J Med Sci. 2020 Oct 15; 8 (F) $260-271$.
Ont. https://doi.org/10.3889/oamjms.2020.4587 Keywords: Botulinum toxin; Oral and maxillofacial surgery;
Dentistry; Applications *Correspondence: Ahmed M. Elmarakby, Ass. Prof. and Chairman of Restorative Dental Sciences Department, Al-Farabi Colleges for Dentistry and Nursing. Riyadh, KSA and Lecturer of Operative Faculty of Dental Medicine, Al-Azhar University. Assiute Branch, Egypt. Mobile: 00966506676440 E-mail: drahmedmarakby@yahoo.com Received: 09-Mar-2020 Revised: 01-Oct-2020 Accepted: 05-Oct-2020
Copyright: $\odot 2020$ Ahmed Wallan Al Ahmary, Sabrin Moshabab Alqhtani, Bshayer Abdullah Alshahrani, Wadiah Abdullah Alkaram,
Bayan Saeed Alhadad, Ahmed . Funding: This research did not receive any financial suppot Funding: This research did not receive any financial support
Competing Interests: The authors have declared that no competing interests exist
compling competing interests exis
caccess article distributed Open Access: This is an opeative Commons Attribution-
under the terms of the Creat NonCommercial 4.0 International License (CC BY-NC 4.0)

\begin{abstract}
Botulinum toxin is a toxin produced by Clostridium botulinum bacteria. This toxin has eight known serotypes, among which both $A$ and $B$ are currently used in medicine. Its mechanism of action acts on inhibiting acetylcholine release at neuromuscular junctions following its local injection. This toxin has wide applications in dentistry in general and in oral and maxillofacial (OMF) surgery in particular. It can be applied in the management of temporomandibular joint disorders, neuropathic facial pain, facial nerve palsy, hypertrophy, and hyperactivity of masticatory muscles as examples. At present, it can be used in cosmetic treatment in the facial region to control wrinkles and asymmetry. The therapeutic effects of these toxins are temporary and relatively safe if used in an appropriate manner. This review was aimed to identify the uses of botulinum toxin in surgical and non-surgical treatment of OMF problems, the types of treatment available, and benefits of those treatments.
\end{abstract}

\section{Introduction}

Oral and maxillofacial (OMF) surgery, according to the American Dental Association, is defined as "the specialty of dentistry which includes the diagnosis, surgical and adjunctive treatment of diseases, injuries, and defects involving both the functional and esthetic aspects of the hard and soft tissues of the OMF region" [1]. It involves any surgery and cosmetic procedure to correct any kind of problem with the mouth, jaws, facial structures, and neck.

The specialty scope is extensive and includes the diagnosis and management of facial injuries, head and neck cancers, salivary gland diseases, facial disproportion, facial pain, impacted teeth, cysts, and tumors of the jaws [2].

Specialized fields of OMF surgery include:

- $\quad$ Cosmetic surgery: Surgery to enhance facial esthetics and improve quality of life
- $\quad$ Surgical treatment of head and neck cancer

- $\quad$ Surgery for craniofacial facial deformity

- Oral medicine

- Craniofacial trauma.

OMF surgical operations can be carried out on an outpatient or inpatient basis under local or general anesthesia, respectively.

Botulinum toxin A (BTA) neurotoxin is one of the most poisonous biological substances known. It is produced by an anaerobic, gram-positive, sporeforming rod bacterium Clostridium botulinum. This bacterium is commonly found on plants, in soil, water, and the intestinal tracts of animals [3].

Different strains of $C$. botulinum produce eight antigenically distinct exotoxins. They include (Type A, B, $C_{1}, C_{2}, D, E, F$, and $G$ ). Types A, B, and E are commonly affected with systemic botulism in human [4].

All serotypes have similar molecular weight and structure that consists of a heavy $(\mathrm{H})$ and light $(\mathrm{L})$ 
chain joined by a disulfide bond [5]. The most potent exotoxin and common form of botulinum toxin for clinical use are the Serotype A [6]. Dysport ${ }^{\circledR}$ and Botox ${ }^{\circledR}$ are examples of commercially available preparations of botulinum toxin.

Botox and dermal fillers are the two main injectable substances used to reduce facial wrinkles and lines. Some medical practitioners may decide to use both types of injectable in achieving the best result to treat deep lines.

Botox ${ }^{\circledR}$, one of the commercially available forms of botulinum toxin type $A$ is the lyophilized form of the strain. It is a purified protein used to temporarily relax facial muscles that cause lines and wrinkles. It is also used in the treatment of muscle spasm and excessive sweating. It relaxes the underlying muscle and allows the skin to flatten out. It works on wrinkles that are caused by muscle movement (dynamic wrinkles) and do not work on wrinkles caused by sagging or loss of plumpness in the face (static wrinkles). It is given intramuscularly to weaken muscles in the face.

Botulinum toxin type $A$ is used on the forehead lines, lines of the throat, lines across the bridge of the nose, frown lines between the eyebrows, and the wrinkles extending from the outside corners of the eyes. The wrinkle-smoothing effect may last for up to 6 months [7].

Fillers have been classified as a cosmetic device used for several esthetic and non-esthetic indications. It has been approved by the Food and Drug Administration (FDA) for only wrinkle management [8]. They work by lifting and smoothing targeted fold and wrinkles by adding subtle volume with the esthetic outcome seen immediately after treatment. They are used as volumizers, lifting and plumping the jawlines, chins, and temples, also filling out thin lips and plumping sagging hands.

There are different types of dermal fillers in use and the use of each type depends on the defect to be corrected, the longevity desired, and the material. The combination of different filler materials at the same time is discouraged due to complications that could arise as a result of the materials [9].

The use of fillers and Botox is gaining attention in medical procedures and it is one of the quickest growing areas of medical specialty. Botox has been found useful in the treatment of irregular gums, temporomandibular joint syndrome, facial pain in faciomaxillary areas, angular cheilitis, bruxism and clenching cases, trigeminal neuralgia, and sialorrhea. Fillers on the other hand are used in filling of rhytids, correction of soft tissue loss due to disease or age, volume replacement, and treatment of gummy smile [10].

A study carried out by Bennett et al., 2016 [11] on the use of Botox in interventional radiology pointed that interventional radiologists with the aid of imaging guidance have been able to deliver the medication (botulinum toxin) to various target sites that are difficult to reach with high accuracy and minimal complications. The use of Botox in interventional radiology was demonstrated by describing the fluoroscopic technique for the treatment of piriformis syndrome.

Another research on the crystallization and preliminary X-ray analysis of botulinum neurotoxin type $A$, it was indicated that after the crystallization of the pure neurotoxin serotype $A$ isolated from the liquid culture of $C$. botulinum, the three different crystal morphologies had the same crystal form with the most suitable crystal form for X-ray analysis the bipyramidal ones which crystallize in hexagonal space group [12].

The detection of botulinum toxin muscle effect in humans using magnetic resonance imaging, a qualitative case series carried out by O' Dell et al., 2017 [13] concluded that the use of magnetic resonance imaging to detect the volume of botulinum toxin muscle effect is feasible and may assist researchers in modeling the spread and diffusion of botulinum toxin within the human muscle.

The expected longevity of treatment with Botox and the need for retreatment may last at least 3 months, but it may reach up to 4-6 months depending on some factors such as the area treated, the injected dose, and the type of the formulation used. Moreover, the frequency of treatment may play a role in the duration of the efficacy. But generally, further trials should be applied to examine the potential influence of patient age, sex, severity of the treated case, and the use of Botox with other treatment modalities to explore more convinced and approved results [14].

Regarding the cost of Botox, generally, it can vary depending on the country and the level of dilution, type of the required treatment, number of units injected, and the number of the sites treated. Furthermore, the prices of newer products such as Dysport ${ }^{\circledR}$ and Xeomin ${ }^{\circledR}$ tend to be lower than Botox ${ }^{\circledR}$, but it may change in the efficacy.

\section{Aim and objectives}

The aim of the study was to evolve a modernized review that identifies the uses of botulinum toxin in surgical and non-surgical treatment of OMF problems, the types of treatment available and the benefits of those treatments.

\section{Methodology}

Scholarly literatures were reviewed to delve into botulinum toxin, its uses, and effectiveness. Databases such as PubMed and Google Scholar were used to identify articles that met the objectives of this 
paper. Articles which discussed the application of Botox in OMF surgery were selected and findings presented.

\section{History}

The history of botulinum toxin is a very interesting one, this toxin poisoning has been thought to affect mankind since ancient times [15]. As far back as 1735-1793 in Germany, several people died after consuming uncooked blood sausages which were thought to be Atropa belladonna poisoning, but this claim was rejected. It was later finalized that a local food "Blunzen" made out of pork stomach was the source of the poisoning [16]. Justinus Christian Kerner, a German physician, studied botulism and named the toxin "Sausage poison," however, he failed to define the suspected biological poison [15]. In 1895, Emile Van Ermengem isolated $C$. botulinum from a piece of ham that had poisoned people in the Belgian village. He named this toxin, "Bacillus Botulinus." In 1949, Dr. Burgen's ASV group discovered that the mechanism by which botulinum toxin works was by blocking neuromuscular transmission [17]. In 1980, Alan B Scott utilized BoNT-A in humans to treat strabismus.

In December 1989, the US FDA approved BoNT-A $\left(\right.$ BOTOX $\left.^{\circledR}\right)$ for the treatment of strabismus, blepharospasm, and hemifacial spasm in patients younger than 12 years. By 2002, it was approved for cosmetic use to temporarily improve the appearance of moderate-severe glabellar lines [18]. During the midand late-1990s, Botox was used in the treatment of crow's feet, orbicularis oris injection, platysma banding, temporomandibular disorders (TMDs), and masseter muscle injection [19]. Over the years, it has been approved for the treatment of several diseases such as severe underarm sweating, prevention of chronic migraine, urinary incontinence, cervical dystonia, and upper limb spasticity, among others [18]. Botulinum toxin is being evaluated constantly for new uses in cosmetology and medicine.

\section{Structure and Types}

Botulinum toxin is a protease produced by C. botulinum, which is an anaerobic, spore-forming, and Gram-positive rod that is found in water, soil, plant, and animal intestinal tract [20]. It is a high molecular weight protein complex that consists of a 150-kDa toxin, a nontoxin hemagglutinin, and a non-toxin non-hemagglutinin protein which are the three key proteins. The $150-\mathrm{kDa}$ toxin comprises a 100-kDa heavy chain and a 50-kDa light chain. The heavy and light chain both required for neurotoxicity are linked by disulfide and non-covalent bonds as shown in Figure 1 [21], [22].

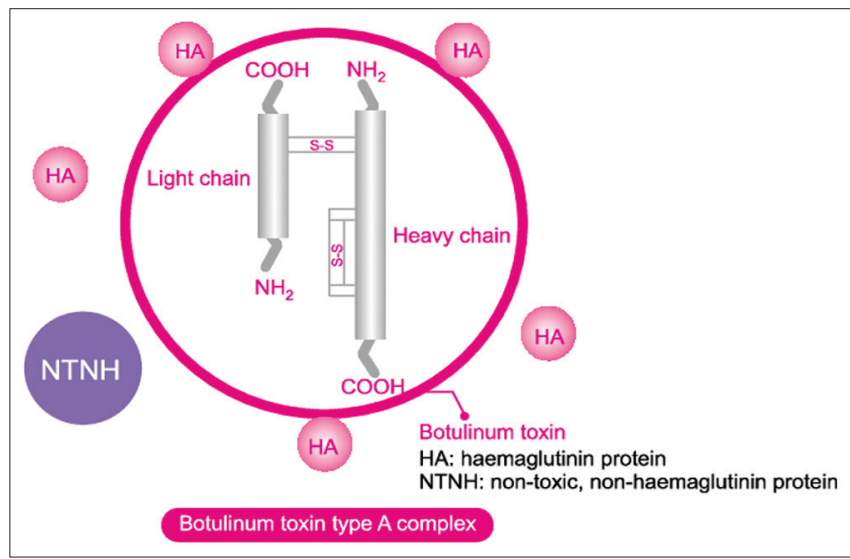

Figure 1: Schematic diagram of botulinum toxin type $A$ (Illustration under courtesy of Rho et al., 2010) [22]

Botulinum toxin has eight serological types that include $A, B, C_{1}, C_{2}, D, E, F$, and $G$. All eight serotypes have corresponding molecular structures and functions; however, only $A, B$, and $E$ are deleterious to the human system, causing botulism. BTA has the strongest toxicity to human. The spores of BTA and B are heat tolerant; however, the neurotoxin is not. The toxin thrives in acidic conditions as it is acid-resistant, but it is intolerant in an alkaline-medium [20].

\section{Mechanism of Action}

All the serotypes of botulinum toxin interfere with neural transmission by blocking the release of acetylcholine (Ach) although have different specific toxicities, duration of persistence in nerve cells, and different potencies [19]. Acetylcholine is the main neurotransmitter at the neuromuscular junction. Upon intramuscular administration of botulinum toxin at the neuromuscular junction, muscle paralysis occurs by inhibition of the release of acetylcholine from the presynaptic motor neurons. Botulinum toxins act at four sites of the body:

\begin{tabular}{|c|c|}
\hline 1 & Neuromuscular junction \\
\hline 2 & Autonomic ganglia \\
\hline 3 & Postganglionic parasympathetic nerve endings \\
\hline 4 & Postganglionic sympathetic nerve endings [4]. \\
\hline & $\begin{array}{l}\text { Botulinum toxin exerts its effect by cleaving } \\
\text { teins required for the activation of nerves. The } \\
\text { chain of the toxin binds explicitly and irreversibly } \\
\text { les that use acetylcholine; then, the resulting } \\
\text { ceptor complex is taken up by the neuron } \\
\text { vesicle by receptor-mediated endocytosis [23]. } \\
\text { sicle acidifies as it moves farther into the cell, } \\
\text { ng a portion that stimulates it to cross from the } \\
\text { membrane into the cell cytoplasm [24]. Inside } \\
\text { oplasm, soluble NSF attachment protein receptor }\end{array}$ \\
\hline
\end{tabular}


protein is cleaved from the toxin inhibiting the cell from releasing vesicles of neurotransmitter [23]. The toxin is released as a single chain from the bacterium and it is activated when broken down by its own protease [25].

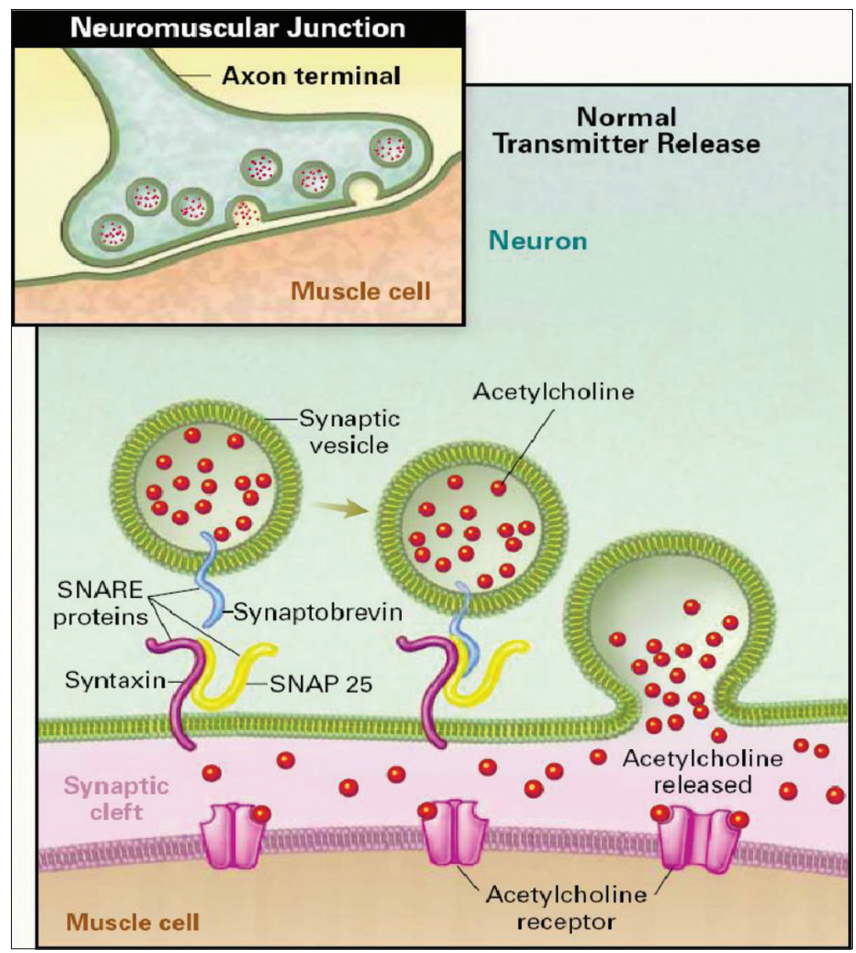

Figure 2a: Diagrammatic representation of the normal release of acetylcholine at the neuromuscular junction (Illustration under courtesy of Čapek and Dickerson, 2010) [26]

Inside the cytoplasm, fusion of acetylcholine vesicles with the cell membrane is prevented by the interaction of the light $(\mathrm{L})$ chain with different proteins (synaptosomeassociated protein 25, vesicle-associated membrane protein and syntaxin) [4], [26] (Figure 2a and b).

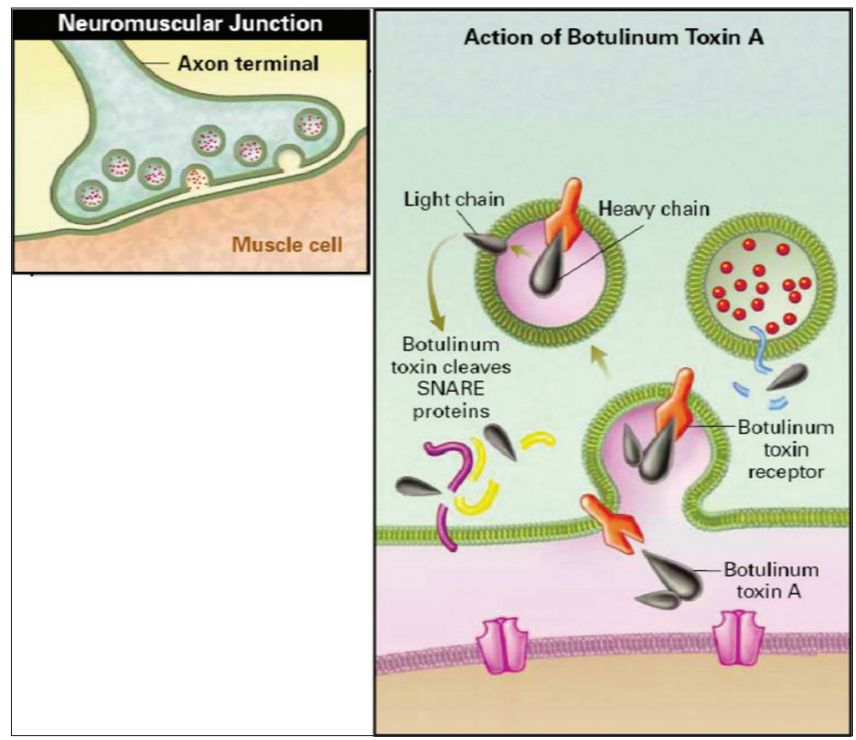

Figure 2b: Diagrammatic representation of the mechanism of action of botulinum toxin at the neuromuscular junction (Illustration under courtesy of Čapek and Dickerson, 2010) [26]

The effect of paralysis occurs within 3-7 days after intramuscular administration, while the maximum effect is seen after 1-2 weeks, then tapers down to a moderate plateau until full nerve recovery within 3-6 months [27].

Botulinum toxin is used in the treatment of muscular overactivity such as dystonia because of its ability to induce weakness of striated muscles by inhibition of alpha motor neurons at the neuromuscular junction. Inhibition of transmission of alpha motor neurons in muscle spindles may alter reflex overactivity [4]. Botulinum toxin inhibits the release of $\mathrm{ACh}$ in all parasympathetic and cholinergic postganglionic sympathetic neurons; this mechanism is utilized in treating overactive smooth muscles (achalasia) or abnormal activity glands (hyperhidrosis) [3].

\section{Preparation and Injection}

There are six types of botulinum toxin available commercially, five contain BTA Botox $^{\circledR}$, Dysport ${ }^{\circledR}$, Xeomin $^{\circledR}$, Prosigne ${ }^{\circledR}$, and PurTox ${ }^{\circledR}$ ) and the last one contains BTX-B (Myoblocs ${ }^{\circledR} /$ Neuroblocs $^{\circledR}$ ) [28]. The dosage form of Myobloc ${ }^{\circledR}$ is a solution unlike Botox ${ }^{\circledR}$ and Dysport $^{\circledR}$ which are in the form of a white powder that needs dilution [20].

The brand or preparation determines the doses of botulinum toxin required for the treatment of a condition, as the unit varies from brand to brand [29].

Botox should be kept in $-50^{\circ} \mathrm{C}$ temperature before use to ensure its potency and efficacy. Its utilized doses depend on its brand, as the unit of one brand is different to the other. The two most commercially available types of BT are Botox ${ }^{\circledR}$ and Dysport ${ }^{\circledR}$. About 20-25 units of Botox ${ }^{\circledR}$ are equivalent in potency to 80 units of Dysport ${ }^{\circledR}$. Botox ${ }^{\circledR}$ is marketed as single-use, sterile 100 units or 200 units vacuum-dried powder while the vial of Dysport ${ }^{\circledR}$ contains 500 units. Its reconstitution be with preservative-free $0.9 \%$ sodium chloride injection USP before injection. The reconstitution should be gentle, as froth formation resulting from vigorous shaking can cause toxin denaturation. It is prepared by adding $4 \mathrm{ml}$ of $0.9 \%$ preservative-free normal saline solution to make injections, and the preparation should be used within $4 \mathrm{~h}$. The preferred syringe is a calibrated $1.0 \mathrm{~mL}$ tuberculin syringe with a gauge preference of 26-30 [29] (Table 1).

The calibrated $1.0 \mathrm{~mL}$ tuberculin syringe is the preferred one for BT injection. The injections are usually delivered while the patient reclining at approximately $25-30^{\circ}$ angle from the vertically upright position. The targeted muscle should be undergone examination by inspection and palpation, while the patient applying facial expressions or during clenching to locate the exact area of injection. The injection site should be sterilized using Betadine. Then, topical anesthesia and 
Table 1: Preparations of botulinum toxin, trade name, indication, and physical properties

\begin{tabular}{|c|c|c|c|c|}
\hline \multirow{3}{*}{$\begin{array}{l}\text { Toxin } \\
\text { Trade name }\end{array}$} & Onabotulinumtoxin-A & Abobotulinumtoxin-A & Incobtulinumtoxin-A & Rimabotulinumtoxin-B \\
\hline & Botox $^{\otimes}$ (Allergan Inc.) & Dysport $^{\oplus}$ (Medicis & Xeomin $^{\circledast}$ (Merz & Myobloc ${ }^{\circledast} /$ Neurobloc $^{\otimes}$ \\
\hline & & Pharmaceutical Corp) & Pharmaceutical) & (Solstice Neurosciences, Inc.) \\
\hline BoNT & A & A & A & B \\
\hline Molecular weight & $900 \mathrm{kD}$ & 500-900 kD & 150 kD & $700 \mathrm{kD}$ \\
\hline Indication & $\begin{array}{l}\text { Blepharospasm, cervical dystonia, primary axillary hyperhidrosis, } \\
\text { urinary incontinence, chronic migraine, upper limb spasticity, } \\
\text { cosmetic use (glabellar wrinkles, etc.) }\end{array}$ & $\begin{array}{l}\text { Blepharospasm, cervical } \\
\text { dystonia, cosmetic use } \\
\text { (glabellar wrinkles, etc.) }\end{array}$ & $\begin{array}{l}\text { Blepharospasm, cervical } \\
\text { dystonia, cosmetic use } \\
\text { (glabellar wrinkles, etc.) }\end{array}$ & Cervical dystonia \\
\hline Units/vial & 100 & 500 & 50,100 & $2500,5000,10000$ \\
\hline Storage prior to opening & $2-8^{\circ} \mathrm{C}$ & $2-8^{\circ} \mathrm{C}$ & $2-8^{\circ} \mathrm{C}$ & $2-8^{\circ} \mathrm{C}$ \\
\hline Shelf life (months) & 36 & 24 & 36 & 24 \\
\hline Storage after opening & $24 \mathrm{~h} / 2-8^{\circ} \mathrm{C}$ & $4 \mathrm{~h} / 2-8^{\circ} \mathrm{C}$ & $24 \mathrm{~h} / 2-8^{\circ} \mathrm{C}$ & $4 \mathrm{~h} / 2-8^{\circ} \mathrm{C}$ \\
\hline
\end{tabular}

BoNT: Botulinum toxin, kD: Kilodalton.

ice should be applied prior to injection to reduce and control the pain and bleeding at the injection site. The Botox is then injected into specified areas as required according to the type of the indication, injected muscle, and the gender (as male muscle has a larger volume than female, thus requiring more units of Botox to achieve the same results as female patients). In case of bleeding, pressure should be applied to the injection site. After finishing, the patient should be in an upright position for 2-5 min to ensure wellness. Post-operative instructions should be given to the patient, which include avoidance of laying down for $4 \mathrm{~h}$, avoidance of excessive physical activity for 1 day to reduce the risk of bruising. In the case of patients complain of pain or headache, non-steroidal anti-inflammatory drugs should be prescribed. Furthermore, to bleeding and edema, it is advisable to recommend the use of ice packs [30].

A study involving 71 patients was carried out among patients with TMD and refractory to conventional treatment. The patients were injected with botulinum toxin (onabotulinumtoxin $A$ ) into the temporalis and masseter muscles. Seventy-seven percent (55 subjects) reported benefits from botulinum toxin, subjective reduction in pain, and/or improvement in function [31].

A double-blinded study was performed to determine the effectiveness of BTA in removing facial wrinkles among esthetic surgery patients who do not have muscular dystonia. Eleven subjects were used, 0.2 cc of either BTA or normal saline was injected into the forehead or periorbital wrinkles. Out of the 11 patients injected with BTA, nine reported a significant improvement of the facial wrinkles compared to the side of the face injected with normal saline. No patient injected with normal saline reported any changes. BTA is effective in eliminating facial wrinkles non-surgically.

A study consisting of 55 patients with acute facial muscle paresis as a result of facial nerve injury during neurosurgical surgery was carried out to assess the importance of botulinum toxin type $A$ on the acute phase of the facial nerve injury. After 4 weeks, significant improvement among the 35 patients administered BTA in the intact side of the face was observed $(p<0.05)$. However, the remaining 20 patients who went through rehabilitation treatment observed improvement by the $12^{\text {th }}$ week. Twelve months after, the number of synkinesis observed in patients who underwent rehabilitation was $46 \%$ higher than the other group. After 24 months, synkinesis was $91 \%$ higher $(p<0.01)$. The results indicated the use of botulinum toxin type $A$ is satisfactory in acute facial nerve injury and should be compulsory in combined therapy for these patients [32].

$A$ randomized survey carried out to compare the effect of BTA with placebo using a subjectreported outcome and also assess the utility of $64 \mathrm{U}$ of BTA to treat the entire upper face. Forty females were randomly administered $64 \mathrm{U}$ of BTA or identical placebo injection of the upper face and followed for 12 weeks. The results were graded using the Facial Line Outcomes Questionnaire (FLO-7) and the selfperception of age (SPA) and significant improvements on the FLO-7 scores were maintained throughout the study. The majority of the subjects reported reduced age of appearance after BTA treatment while placebo had no effect. Sixty-four units of BTA was used in the treatment of upper facial rhytids as indicated by the FLO-7 and SPA scoring.

\section{Clinical Application of Botulinum Toxin in OMF Surgery}

Botulinum toxin has gained popularity since it has been introduced to be therapeutically relevant [33]. It is a bacterial toxin which has evolved from a poison to a clinical agent used for a number of conditions caused by muscular hyperfunction. The clinical uses of botulinum toxin have been growing over the last 30 years and new applications reported [19].

\section{Cosmetic application}

Botulinum toxin is popularly known for its use in cosmetology [29]. Using fillers alongside with BTX, the practitioner is able to sculpt the patient's face by altering the facial muscles dynamic [19].

Facial wrinkles: Botulinum toxin is used in wrinkle therapy for glabella lines and platysma bands [34]. Glabella lines are spontaneous facial animation that develops when the lower facial muscles pull the skin; it becomes more 
obvious with constant exercise and aging [35]. The administration of this toxin is generally simple. The process involves injecting the adequate dose perpendicularly, considering the anatomy of the region to be treated. It is injected at a distance from the major structures like the bony orbit since the toxin is known to diffuse to approximately $10 \mathrm{~mm}$ [36]. Injection technique: The targeted glabellar complex muscles can be identified by allowing the patient to actively frown, then injections are delivered into the contracted muscles. Small volumes of botulinum toxin solution are injected, typically $1 \mathrm{~mL}$ or less, using a 30-gauge, 1 -inch needle. There are five injection sites, one injection in the procerus muscle and two in each of the corrugator supercilii muscles (Rebecca Small, 2014) (Figure 3) [29].

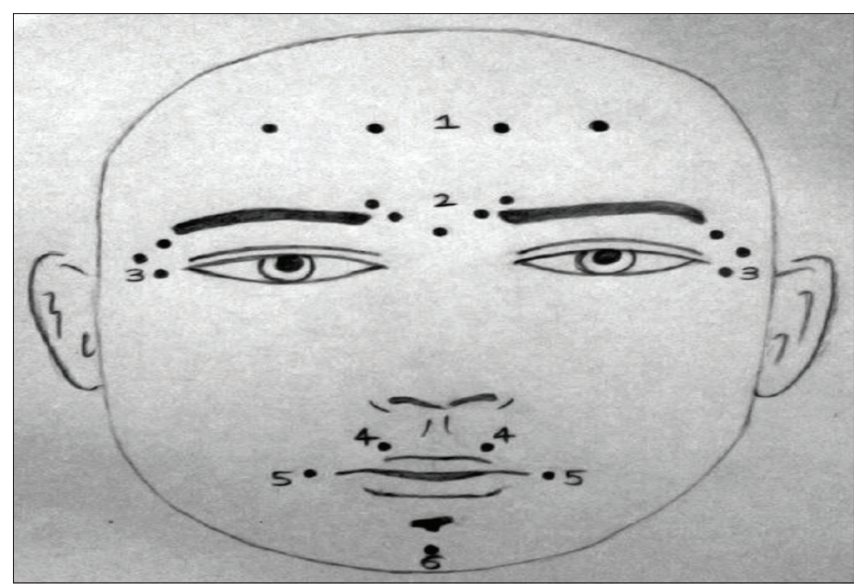

Figure 3: BTA injection sites on the face (Illustration under courtesy of Srivastava et al., 2015) [29]

- Masseteric and temporalis muscle hypertrophy: Masseteric hypertrophy may be unilateral or bilateral. It usually results from the anatomical asymmetry of the jaw, clenching during exercise or sleep, congenital malformations, or excessive chewing of gum. The effect of treatment with the intra masseter injections of botulinum toxin has been encouraging and satisfying but not well quantified [36], [37].

Temporalis muscle hypertrophy though less common has been successfully managed with botulinum toxin injection with no appreciable side effects observed [38].

- Injection technique: The dose administered is $12 \mathrm{U}$ of BTA percutaneously into the thickest part of the muscle; the injection site is identified by palpation during clenching [39].

- Dentofacial esthetics and gummy smile: Both botulinum toxin and dermal fillers administered into the interdental papilla are recently being used to deliver immediate volume to black triangles formed due to the inadequate or loss interpapillary tissue [40], [41]. Botulinum toxin is particularly effective in managing cases of excessive gingival display due to inordinate contraction of the upper lip muscles [42].

- Injection technique: A point known as "Yonsei point" which is located at the center of the triangle formed by levator labii superioris, levator labii superioris alaeque nasi, and zygomaticus minor. The recommended dose is $3 \mathrm{U}$ at each injection site. The depth of administration should be intramuscular with the needle perpendicular to the skin surface and bevel facing upwards [43].

- $\quad$ Drooping of corners of mouth: This can result from hyperactivity of the depressor anguli oris. The injection of botulinum toxin on the trajectory of the nasolabial fold to the jaw line showed positive results [44].

Injection technique: The site of injection is on the trajectory of the nasolabial fold to the jawline. Bilateral injections in doses of about 2-5 $U$ are the norm.

\section{Therapeutic application}

From a poison, botulinum toxin has evolved to a universal clinical tool for a growing list of conditions resulting from muscular hyperfunction. It has recently been reported for clinical use in dental implantology for the prophylactic reduction of masseter and temporalis strength after implantation in immediate load protocols [45]. In the head and neck, the muscular hyperfunction managed with this toxin includes vocal tics and stuttering, hemifacial spasm, temporomandibular joint (TMJ) dysfunction, bruxism, sialorrhea, hyperhidrosis, various manifestations of a tumor, and masticatory myalgia [37].

\section{$T M D$}

One of the major causes of pain in the orofacial region is the TMD, which is subgroups of musculoskeletal and rheumatologic disorders. These disorders can be classified based on those related to the muscle acting on the joint (myofascial) and those related to the joint itself (arthrogenic).

Injections with botulinum toxin are performed under electromyographic or ultrasonic control [37]. The toxin relieves pain caused by hyperactivity in TMD as well as the pain in the masticatory muscles and it has been successful in the treatment of temporomandibular joint dislocation [46]. It is administered intramuscularly into the adjacent muscles (masseter and temporalis), causing relaxation and improving muscle inflammation which in turn leads to improved mouth opening. This has helped in the improved parafunction such as clenching as well as bruxism (grinding of the teeth) and TMD symptoms [47].

Patients suffering from TMD usually have mouth-opening restriction; BTA relaxes the adjacent 
masticatory muscles and improves inflammation of muscles resulting to improve mouth opening [20]. The use of BTA injection into masticatory muscles (such as lateral pterygoid muscles) has a good outcome therapeutically [20], [29] (Figure 4).

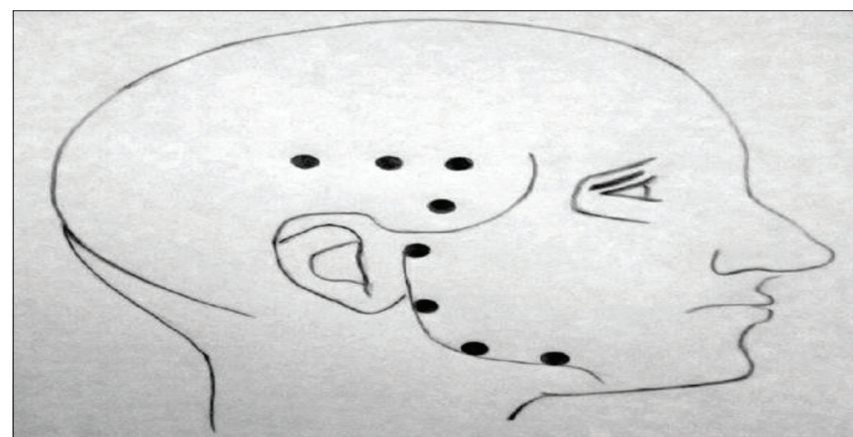

Figure 4: Injection sites forbotulinum toxin type Ain temporomandibular joint (IIlustration under courtesy of Srivastava et al., 2015) [29]

The following are groups of TMDs that have high chances of benefitting from BTX:

- $\quad$ Bruxism and clenching

- Orofacial myofunctional disorders

- Myofascial pain

- Headaches

- Trismus

- $\quad$ Masseter and temporalis hypertrophy [29]

- $\quad$ Anterior displacement of articular disk [48].

\section{Injection technique}

- $\quad$ Extraoral: The involved muscles here are the masseter and temporalis muscles which express direct muscle pain. To determine the injection site, the patient is requested to clench his/her teeth to make the injection site clear and easily detected. The Botox injection applied bilaterally to limit these muscles contraction. The starting dose of Botox 10-25 $U$ for a temporalis muscle, $25-50 \mathrm{U}$ to a masseter muscle. It is preferred to give an injection in multiple sites with low doses to avoid incomplete effect and to reduce the unwanted diffusion to the undesired adjacent areas, with possible causing of brow ptosis, diplopia in temporalis muscle injections, and asymmetry in the case of masseter muscle. As well mouth dryness may occur in case that Botox was accidentally injected into the parotid gland [49].

- Intraoral: Lateral pterygoid muscle involvement can be manifested as buccal pain and involved in the anterior displacement of the articular disk. The muscle position can be identified intraorally with the guidance of electromyogram to determine the exact place for the needle to be placed between the pterygoid plate and the coronoid process of the mandible. The desired Botox dose for this muscle is 7.5-10 U. Furthermore, this muscle can be approached extraorally through space formed by the zygomatic arch and the sigmoid notch of the mandible below the center of the zygomatic arch. The needle will be advanced perpendicular to the skin with mouth closed. The muscle is approximately $3-4 \mathrm{~cm}$ deep. The patient will be asked to move the mandible laterally [50].

- $\quad$ Salivary gland secretory disorders

Investigation of botulinum toxin on its application for sialorrhea (excessive salivation) and drooling was carried out as a result of xerostomia, one of the manifestations of botulism. The topical injection of this toxin has been used for many years in neurological diseases as a minimally invasive option for the treatment of drooling [51], [52]. The therapeutic effect is based on the inhibitory action of the toxin at the cholinergic receptors of the salivary gland cells [53]. Botulinum toxin has been applied for sialorrhea in Parkinson's disease [54], amyotrophic lateral sclerosis [55], cerebral palsy [56], and carcinoma of the upper digestive tract. It has also been shown to be effective in the treatment of Frey's syndrome as it reduces the skin area affected by gustatory sweating [57] by inhibiting the sweat glands abnormally re-innervated by the cholinergic pathway [58]. The injection is given into the parotid and submandibular glands [59].

- Injection technique: Botox injection into the parotid and submandibular gland control the salivary drooling. The required dose is ranged between 30 and $70 \mathrm{U}$. However, this effect in the reduction of salivary flow will fade in about 3 months, so repeated doses may be required [60].

- Facial pain and trigeminal neuralgia: Botulinum toxin was found to be safe and effective in the management of pains in the maxillofacial region as well as in the case of trigeminal neuralgia without major side effects [45], [61]. The injection showed some advantages over existing therapies regarding safety and efficacy [62]. It was found propitious in post-operative wound pain, including reconstructive facial and oral surgery, traditional and endoscopic sinus surgery, and blowout fracture repair [63].

- Injection technique: For the injection to the maxillary root, a dental needle of $0.40 \times 50$ $\mathrm{mm}$ is used through the upper edge of the zygomatic arch, midway between the external ear and the orbital rim; the needle should be pointed toward the zygomatic bone on the other side of the skull at a depth of $50 \mathrm{~mm}$ around the pterygopalatine ganglion. While for the injection to the mandibular root, through the lower edge of the zygomatic arch, the position should be the same. The needle should be pointed transversely along the base of the skull toward the middle, then to be inserted below the middle of the zygomatic arch. After striking 
the pterygoid process, the needle should be withdrawn slightly craniodorsally about 5-10 $\mathrm{mm}$, where the solution is administered around the trigeminal ganglion [64].

Facial nerve palsy: Botulinum toxin injection through an orbital route or a skin crease delivers a good means of inducing protective ptosis which may be useful in intensive care patients to prevent desiccation of the cornea [65]. It was found to improve facial expression symmetry both at rest and in voluntary movements because of its effectiveness in reducing facial synkinesis, an involuntary uncoordinated muscle movement associated with the voluntary movement of the muscle [66]. Administration of this toxin into the lacrimal gland helps to successfully manage hyperlacrimation (crocodile tears), one of the complications of facial nerve palsy [67]. Injection technique: The areas of injection include levator labii alaeque nasi to reduce the visibility of the upper teeth; depressor labii inferioris to reduce the visibility of the lower teeth and orbicularis oculi and frontalis to match the contralateral rhytids. The patient should be seated in an upright position with the head supported and asked to smile widely; then, sites of injection are examined clinically to exhibit the maximum pull on the movement of the lower face are marked and are injected at an angle of $45^{\circ}$ intramuscularly. The unaffected side is also injected to make balance, improve hyperkinesis, and give more symmetry at rest [68].

Bruxism: This is the act of severe clenching or grinding of teeth and is usually associated with attrition, headache, muscular pains, and TMJ dysfunction symptoms. Botulinum toxin is effective in the treatment of bruxism [69]. BTA is encouraged for the treatment of sleep bruxism [70]. A single dose of injection is effective for about month duration [71].

Injection technique: Injection areas are identified by palpation during clenching, then bilateral injections of Botox are injected in three sites in the thickest parts of the masseter muscles with a dose range of 25-100 U/side [39].

- $\quad$ Adjuvant for wound healing after OMF surgery: After surgery, the healing of the surgical site can be inhibited in the presence of inappropriate movements of the muscles adjacent to this surgical site. Botulinum toxin injections when administered pre- or post-operative can facilitate healing by weakening the muscles. Wound healing improves if the muscles involved are injected with the toxin before surgery [72]. Reports showed that botulinum toxin injection into the masticatory muscles of patients with jaw fractures, which is a very common treatment in OMF surgery, prevents bone displacement [45].
Implantology: Although the literature supporting the use of botulinum toxin in implantology is scarce [45], it has been postulated that the toxin is therapeutically useful in relaxing the masticatory muscles. This spares the implant leading to unimpeded osseointegration since stress due to any excessive functional force, or any parafunctional habit may cause implant failure [73].

- $\quad$ Adjunct to orthodontic treatment and to prevent relapse: Patients having strong muscle activity such as that of mentalis muscle may have relapsed following an orthodontic (irregularity of the teeth) correction. Botulinum toxin can be used during treatment to reduce the intensity of muscle contractions and muscles can be trained slowly and gradually to a more physiologic movement [74]

- $\quad$ OMF trauma: Botulinum toxin in higher doses may be used as a pharmaceutical splint during the management of fractured facial bone. Injection of the toxin into the anterior belly digastric has been successfully used in the correction of post-traumatic anterior open bite [75]

- $\quad$ Denture wearers: The jaw muscles can alter their size, cross-sectional areas, and properties to adapt themselves to the changing demands in terms of function [76]. Patients who are trying to adapt to a new set of dentures due to irregular and uncoordinated muscle activity can be treated with BTA. Patients who have been toothless (Edentulous) for a long period of time benefit from BTA therapy as it provides muscle relaxation [29].

\section{Diagnostic application}

BTA can be used as a prophylactic and diagnostic in patients with a chronic intermittent toothache. The toxin can be used to confirm the source of the pain, to identify if it is muscular or pulpal. This can be used in cases with referred pain from anterior temporalis [29].

\section{Guidelines for Administration}

There are necessary guidelines to be followed when administering the botulinum toxin. They include:

1 The preparation should be used within the first $4 \mathrm{~h}$

2 A lower dose of the toxin should be used as a start dose

3 The muscles should not be paralyzed completely 
$4 \quad$ The site or area of injection should be covered with a topical anesthetic cream or can be anesthetized with ice

5 Males generally require a higher dose due to larger muscle masses [29].

Treatment using botulinum toxin is palliative rather than curative. This is because the blockade is temporary and it lasts for 3-4 months, after which there is sprouting of new axon terminals resulting in the return of normal neuromuscular function [77].

\section{Side Effects}

Immunogenicity, allergy, and local complications are the major side effects experienced after the cosmetic use of botulinum toxin [19]. The adverse effects of BTA that may occur after injection include pain, erythema, edema, ecchymosis, and hypoesthesia [36]. Headache is the most common side effect and begins within 24 $\mathrm{h}$ after injection; however, it subsides with increasing the frequency of injection [20]. Blepharoptosis and peripheral muscular palsy are among other adverse effects of the toxin. Systemic side effects such as transient weakness, fatigue, nausea, and pruritus are rarely reported and usually not dose-related. Treatment with botulinum toxin $B$ has reported more cases of xerostomia and dysphagia [19]. A brief duration of flusymptoms has also been reported [37].

\section{Complications}

The therapeutic index of botulinum toxin is large [78]. The complications of BTA injection can be systemic, local, and reduced therapeutic effects as a result of antibody formation [20]. Complications are seen more when BTA is used for therapeutic treatment than for cosmetic purposes, this is as a result of higher doses used in therapeutic purposes [34].

Loss of effect of the treatment can be experienced due to neutralizing antibodies to botulinum toxin-A. It has been reported that about $7 \%$ of patients on BTA experience resistance, this has led to the investigation of botulinum toxin $B$ as an alternative therapy [19]. Regular BTA injection over a short period of time, high doses of injection, and dose increment of BTA injections increase the risk of production of neutralizing antibodies [79].

During the course of therapy, the complications experienced are mostly local and usually mild such as erythema, pain, ecchymosis at the injected site, mouth droop, dry eyes, asymmetry of facial expression during dynamic facial movements, ptosis and lid edema, facial muscle weakness, transient dysphagia, infection, weakness, difficulty in chewing, breathing risk aspiration, recurrent jaw dislocation, salivary duct calculi, xerostomia, nasal speech, nasal regurgitation, headache, blurred vision, dizziness, gastrointestinal upset, weakness, voice changes, and local injuries of carotid arteries or branches of facial nerves [19]. Some complications were reported following intraoral injection into the lateral pterygoid muscle for management of masticatory myofascial pain as pterygoid hematoma, dysarthria, and dysphagia [80].

\section{Contraindications}

Contraindications to Botox include patients with neuromuscular junction abnormalities (such as myasthenia, gravis, myopathies, and amyotrophic lateralizing sclerosis), drug interaction with drugs such as aminoglycosides, quinidine, magnesium sulfate, polymyxin, succinylcholine, and calcium channel blockers [19]. BTA is a category C drug (animal studies show risk and human studies are not available or neither animal nor human studies have been carried out). Due to this, pregnant or breast-feeding women should not use BTA. Patients with systemic diseases such as asthma and arrhythmia should use BTA with extreme caution, especially those who have a previous incidence of adverse reactions [81].

\section{Conclusion}

The journey of botulinum toxin from a deadly toxin to a beneficial therapeutic drug is a tremendous advancement to medicine. The clinical applications of BoTX in OMF surgery are numerous, they include removal of facial wrinkles, drooping corners of mouth, temporalis and masseter muscle hypertrophy, and cosmetic use. Therapeutic uses include treating facial pain, salivary secretory problems, muscle movement disorders, and nerve palsies. The relevance of botulinum toxin in OMF surgery cannot be over-emphasized.

\section{References}

1. Oral-Maxillofacial Surgery Associates. What is Oral Maxillofacial Surgery; 2019. Available from: https://www.omsanewmexico. com/patient-information/what-is-oral-maxillofacial-surgery. [Last accessed on 2019 Feb 22]. https://doi.org/10.1201/b17980-7

2. Royal College of Surgeons. Oral and Maxillofacial Surgery; 2018. Available from: https://www.rcseng.ac.uk/news-and-events/ 
media-centre/media-background-briefings-and-statistics/oraland-maxillofacial-surgery. [Last accessed on 2019 Feb 20].

3. Münchau A, Bhatia KP. Uses of botulinum toxin injection in medicine today. BMJ. 2000;320(7228):161-5. https://doi. org/10.1136/bmj.320.7228.161

PMid:10634738

4. Nigam PK, Nigam A. Botulinum toxin. Indian J Dermatol. 2010;55(1):8-14. https://doi.org/10.4103/0019-5154.60343 PMid:20418969

5. Edmonds $\mathrm{K}$, editor. Dewhurst's Textbook of Obstetrics and Gynaecology. Ch. 49. John Wiley and Sons; 2011. p. 540.

6. Başar $\mathrm{E}$, ArıCı C. Use of botulinum neurotoxin in ophthalmology. Turk J Ophthalmol. 2016; 46(6):282-90. https://doi.org/10.4274/ tjo. 57701

\section{PMid:28050326}

7. Better Health Channel. Cosmetic Treatments Injectables; 2018 Available from: https://www.betterhealth.vic.gov.au/health/ conditionsandtreatments/cosmetic-treatments-injectables. [Last accessed on 2019 Feb 21].

8. Food and Drug Administration. Fillers; 2009. Available from: http:// www.fda.gov/Medicaldevices/productsandmedicalprocedures/ cosmeticdevices/wrinklefillers/default.html. [Last accessed on 2010 Feb 21].

9. Vedamurthy M. Standard guidelines for the use of dermal fillers. Indian J Dermatol Venereol Leprol. 2008;74(7):23-7. PMid:18688100

10. Sinha A, Hurakadli M, Yadav P. Botox and derma fillers: The twin face of cosmetic dentistry. Int J Contemp Dent Med Rev. 2015;2015:131214.

11. Bennett JD, Miller TA, Richards RS. The use of Botox ${ }^{\circledR}$ in interventional radiology. Tech Vasc Interv Radiol. 2006;9(1):36-9. PMid: 17145484

12. Stevens RC, Evenson ML, Tepp W, DasGupta BR. Crystallization and preliminary $\mathrm{X}$-ray analysis of botulinum neurotoxin Type A. J Mol Biol. 1991;222(4):877-80. https://doi. org/10.1016/0022-2836(91)90581-p

PMid: 10944343

13. O'Dell MW, Villanueva M, Creelman C, Telhan G, Nestor J, Hentel KD, et al. Detection of botulinum toxin muscle effect in humans using magnetic resonance imaging: A qualitative case series. PM R. 2017;9(12):1225-35. https://doi.org/10.1016/j. pmrj.2017.04.014

PMid:28483684

14. Flynn TC. Botulinum toxin: Examining duration of effect in facial aesthetic applications. Am J Clin Dermatol. 2010;11(3):183-99. PMid:20369902

15. França K, Kumar A, Fioranelli M, Lotti T, Tirant M, Roccia MG. The history of Botulinum toxin: from poison to beauty. Wien Med Wochenschr. 2017;167(1):46-8. https://doi.org/10.1007/ s10354-017-0553-7

PMid:28299552

16. Sätilä $\mathrm{H}$. The route of botulinum toxin from cause of food poisoning to medical remedy. Duodecim. 2014;130(15):1523-30. PMid:25211822

17. Erbguth FJ. From poison to remedy: The chequered history of botulinum toxin. J Neural Transm. 2008;115(4):559-65. https:// doi.org/10.1007/s00702-007-0728-2 PMid: 17458494

18. Medscape. Botulinum Toxin: Overview; 2018. Available from: https://www.emedicine.medscape.com/article/325451overview\#a2. [Last accessed on 2019 Feb 21].

19. Majid OW. Clinical use of botulinum toxins in oral and maxillofacial surgery. Int J Oral Maxillofac Surg. 2009;39:197207. https://doi.org/10.1016/j.ijom.2009.10.022

\section{PMid:19959337}

20. Park K, Chi-Heun L, Jung-Woo L. Use of botulinum toxin a in dentistry and oral and maxillofacial surgery. J Dent Anesth Pain Med. 2016;16(3):151-7.

PMid:28884147

21. Huang W, Foster JA, Rogachefsky AS. Pharmacology of botulinum toxin. J Am Acad Dermatol. 2000;43(2):249-59.

PMid: 10906647

22. Rho NK, Kim HS, Kim YS, Kim YJ, Kim CH, Kim YS, et al. Botulinum toxin Type $A$ for facial wrinkles and benign masseter hypertrophy in Korean patients. Korean J Dermatol. 2010;48(10):823-31.

23. Dressler D, Saberi FA, Barbosa ER. Botulinum toxin: mechanisms of action. Arq Neuropsiquiatr. 2005;63(1):180-5. https://doi.org/10.1590/s0004-282×2005000100035 PMid: 15830090

24. Montecucco C, Molgó J. Botulinal neurotoxins: Revival of an old killer. Curr Opin Pharmacol. 2005;5(3):274-9. https://doi. org/10.1016/j.coph.2004.12.006

PMid: 15907915

25. Felber ES. Botulinum toxin in primary care medicine. J Am Osteopath Assoc. 2006;106(10):609-14.

PMid:17122031

26. Čapek, P, Dickerson TJ. Sensing the deadliest toxin Technologies for botulinum neurotoxin detection. Toxins (Basel). 2010;2(1):24-53. https://doi.org/10.3390/toxins2010024 PMid:22069545

27. SadickNS, Matarasso SL. Comparison of botulinum toxins Aand B in the treatment of facial rhytides. Dermatol Clin. 2004;22(2):221 6. https://doi.org/10.1016/s0733-8635(03)00040-8 PMid:15222583

28. Troung DD, Jost WH. Botulinum toxin: Clinical use (review). Parkinsonism Relat Disord. 2006;12(6):331-55.

PMid: 16870487

29. Srivastava S, Kharbanda S, Pal US, Shah V. Applications of botulinum toxin in dentistry: A comprehensive review. Natl J Maxillofac Surg. 2015;6(2):152-9. https://doi. org/10.4103/0975-5950.183860

\section{PMid:27390488}

30. Mazzuco R, Hexsel D. Gummy smile and botulinum toxin A new approach based on the gingival exposure area. J Am Acad Dermatol. 2010;63(6):1042-51. https://doi.org/10.1016/j. jaad.2010.02.053

PMid:21093661

31. Connelly ST, Myung J, Gupta R, Tartaqlia GM, Gizdulich A Yang J, et al. Clinical outcomes of botox injections for chronic temporomandibular disorders: Do we understand how botox works on muscle, pain and the brain? Int J Oral Medicine Surg. 2017;46(3):322-7. https://doi.org/10.1016/j.ijom.2016.11.004 PMid:27908491

32. Orlova OR, Akulov MA, Usachev DI, Taniashin SV, Zakharov VO, Saksonova EV, et al. The use of botulinum toxin Type A in the acute phase of facial nerve injury after neurosurgical surgery. Zh Vopr Neirokhir Im N N Burdenko. 2014;78(6):50-4. https://doi. org/10.17116/neiro201478650-54 PMid:25809169

33. Tater P, Pandey S. Botulinum toxin in movement disorders. Neurol India. 2018;66(7):79-89. https://doi. org/10.4103/0028-3886.226441 PMid:29503330

34. Bhogal PS, Hutton A, Monaghan A. A review of the current uses of botox for dentally-related procedures. Dent Update. 2006;33(3):165-8. https://doi.org/10.12968/denu.2006.33.3.165 


\section{PMid:16700273}

35. Hegedus F, Diecidue R, Taub D, Nyirady J. Non-surgical treatment modalities of facial photodamage: Practical knowledge for the oral and maxillofacial professional. Int J Oral Maxillofac Surg. 2006;35(5):389-98. https://doi.org/10.1016/j. ijom.2005.09.011 PMid: 16352420

36. Niamtu III J. Botulinum toxin A: A review of 1,085 oral and maxillofacial patient treatments. J Oral Maxillofac Surg 2003;61(3):317-24. https://doi.org/10.1053/joms.2003.50069 PMid:12618971

37. Bentsianov B, Francis A, Blitzer A. Botulinum toxin treatment of temporo-mandibular disorders, masseteric hyper-trophy, and cosmetic masseter reduction. Oper Tech Otolaryngo Head Neck Surg. 2004;15(2):110-3. https://doi.org/10.1016/j. otot.2004.02.002

38. Isaac AM. Unilateral temporalis muscle hypertrophy managed with botulinum toxin Type $\mathrm{A}$. $\mathrm{Br} \mathrm{J}$ Oral Maxillofac Surg. 2000;38(5):571-2. https://doi.org/10.1054/bjom.2000.0298 PMid:11010798

39. Jaspers GW, Pijpe J, Jansma J. The use of botulinum toxin Type A in cosmetic facial procedures. Int J Oral Maxillofac Surg. 2011;40(2):127-33. https://doi.org/10.1016/j.ijom.2010.09.014 PMid:20965695

40. Amin V, Amin V, Swathi D, Shetty P. Enhancing the smile with botox case report. Glob J Med Res. 2014;13:15-8.

41. Tezel A, Fredrickson $\mathrm{GH}$. The science of hyaluronic acid dermal fillers. J Cosmet Laser Ther. 2008;10(1):35-42

PMid:18330796

42. Polo M. Botulinum toxin Type A (Botox) for the neuromuscular correction of excessive gingival display on smiling (gummy smile). Am J Orthod Dentofacial Orthop. 2008;133(2):195-203. https://doi.org/10.1016/j.ajodo.2007.04.033 PMid:18249285

43. Mostafa D. A Successful management of sever gummy smile using gingivectomy and botulinum toxin injection: A case report. Int J Surg Case Rep. 2018;42:169-74. https://doi.org/10.1016/j. ijscr.2017.11.055

PMid:29248835

44. Choi YJ, Kim JS, Gil YC, Phetudom T, Kim HJ, Tansatit T, et al Anatomical considerations regarding the location and boundary of the depressor anguli oris muscle with reference to botulinum toxin injection. Plast Reconstr Surg. 2014;134(5):917-21. https://doi.org/10.1097/prs.0000000000000589

PMid:25347627

45. Ihde SK, Konstantinovic VS. The therapeutic use of botulinum toxin in cervical and maxillofacial conditions: An evidence-based review. Oral Surg Oral Med Oral Pathol Oral Radiol Endod. 2007;104(2):e1-11. https://doi.org/10.1016/j.tripleo.2007.02.004 PMid:17560141

46. Kim HS, Yun PY, Kim YK. A clinical evaluation of botulinum toxin-a injections in the temporomandibular disorder treatment. Maxillofac Plast Reconstr Surg. 2016;38(1):5. https://doi. org/10.1186/s40902-016-0051-7

PMid:26855937

47. Freund B, Schwartz M. Temporal relationship of muscle weakness and pain reduction in subjects treated with botulinum toxin A. J Pain. 2003;4(3):159-65. https://doi.org/10.1054/ jpai.2003.435 PMid:14622713

48. Ataran R, Bahramian A, Jamali Z, Pishahang V, Barzegani HS Sarbakhsh $P$, Yazdani J. The role of botulinum toxin a in treatment of temporomandibular joint disorders: A review. J Dent Shiraz Univ Med Sci. 2017;18(3):157-64.

\section{PMid:29034269}

49. D'Elia JB, Blitzer A. Temporomandibular disorders, masseteric hypertrophy, and cosmetic masseter reduction. In: Botulinum Neurotoxin for Head and Neck Disorders. Vol. 28. Thieme; 2012. p. 141-51. https://doi.org/10.1055/b-0034-84394

50. Kurtoglu C, Gur OH, Kurkcu M, Sertdemir Y, Guler-Uysal F, Uysal $H$. Effect of botulinum toxin-A in myofascial pain patients with or without functional disc displacement. J Oral Maxillofac Surg. 2008;66(8):1644-51. https://doi.org/10.1016/j. joms.2008.03.008

PMid:18634953

51. Giess R, Naumann M, Werner E, Riemann R, Beck M, Puls I, et al. Injections of botulinum toxin A into the salivary glands improve sialorrhoea in amyotrophic lateral sclerosis. $J$ Neurol Neurosurg Psychiatry. 2000;69(1):121-3. https://doi. org/10.1136/jnnp.69.1.121

PMid:10864618

52. Porta M, Gamba M, Bertacci G. Treatment of sialorrhea with ultrasound guided botulinum toxin Type A injections in patients with neurological disorders. J Neurol Neurosurg Psychiatry. 2001;70(4):538-54. https://doi.org/10.1136/jnnp.70.4.538 PMid:11254784

53. Ellies M, Laskawi R, Tormählen G, Götz W. The effect of loca injection of botulinum toxin $A$ on the parotid gland of the rat: An immunohistochemical and morphometric study. J Oral Maxillofacial Surg. 2000;58(11):1251-6. https://doi.org/10.1053/ joms.2000.16625

54. Lagalla G, Millevolte M, Capecci M, Provinciali L, Ceravolo MG. Botulinum toxin Type A for drooling in Parkinson's disease: A double-blind, randomized, placebo-controlled study. Mov Disord. 2006;21(5):704-7. https://doi.org/10.1002/mds.20793 PMid:16440332

55. Verma A, Steele J. Botulinum toxin improves sialorrhea and quality of living in bulbaramyotrophic lateral sclerosis. Muscle Nerve. 2006;34(2):235-7. https://doi.org/10.1002/mus.20545 PMid:16583370

56. Suskind DL, Tilton A. Clinical study of botulinum-A toxin in the treatment of sialorrhea in children with cerebral palsy. Laryngoscope. 2002;112(1):73-81. https://doi. org/10.1097/00005537-200201000-00014

\section{PMid:11802042}

57. Capaccio P, Torretta S, Osio M, Minorati D. Botulinum toxin therapy: A tempting tool in the management of salivary secretory disorders. Am J Otolaryngol. 2008;29(5):333-8. https://doi. org/10.1016/j.amjoto.2007.10.003

PMid:18722890

58. Drummond P. Mechanism of gustatory flushing in Frey's syndrome. Clin Auton Res. 2002;12:144-6.

\section{PMid:12269544}

59. Benson J, Daugherty KK. Botulinum toxin A in the treatment of sialorrhea. Ann Pharmacother. 2007;41(1):79-85. https://doi. org/10.1345/aph.1h381

PMid:17190848

60. Philouze P, Vertu D, Ceruse P. Bilateral gustatory sweating in the submandibular region after bilateral neck dissection successfully treated with botulinum toxin. $\mathrm{Br} \mathrm{J}$ Oral Maxillofac Surg. 2014;52(8):761-3. https://doi.org/10.1016/j.bjoms.2014.06.008 PMid:24996697

61. Guardiani E, Sadoughi B, Blitzer A, Sirois D. A new treatment paradigm for trigeminal neuralgia using botulinum toxin Type A. Laryngoscope. 2014;124(2):413-7. https://doi.org/10.1002/ lary. 24286

PMid:23818108

62. Borodic G, Acquadro M. Management of facial pain with 
botulinum toxin in a tertiary pain clinic. Naunyn Schmiedebergs Arch Phannacol. 2002;365(2):R14.

63. Borodic GE, Acquadro MA. The use of botulinum Toxin for the treatment of chronic facial pain. J Pain. 2002;3(1):21-7. https:// doi.org/10.1054/jpai.2002.27142

PMid: 14622850

64. Börü ÜT, Duman A, Bölük C, Duman SC, Taşdemir M. Botulinum toxin in the treatment of trigeminal neuralgia: 6-month follow-up. Medicine. 2017;96(39):e8133. https://doi.org/10.1097/ md.0000000000008133 PMid:28953646

65. Freund BJ, Schwartz M. Treatment of chronic cervicalassociated headache with botulinum toxin $A$ : $A$ pilot study. Headache. 2000;40(3):231-6. https://doi. org/10.1046/j.1526-4610.2000.00033.x PMid:10759926

66. Toffola ED, Furini F, Redaelli C, Prestifilippo E, Bejor M. Evaluation and treatment of synkinesis with botulinum toxin following facial nerve palsy. Disabil Rehabil. 2010;32(17):14148. https://doi.org/10.3109/09638280903514697 PMid:20156046

67. Montoya FJ, Riddell CE, Caesar R, Hague S. Treatment of gustatory hyperlacrimation (crocodile tears) with injection of botulinum toxin into the lacrimal gland. Eye. 2002;16(6):705-9. https://doi.org/10.1038/sj.eye.6700230

PMid:12439663

68. Cabin JA, Massry GG, Azizzedah B. Botulinum toxin in the management of facial paralysis. Curr Opin Otolaryngol Head Neck Surg. 2015;23(4):272-80. https://doi.org/10.1097/ moo.0000000000000176 PMid:26101876

69. Tan EK, Jankovic J. Treating severe bruxism with botulinum toxin. J Am Dent Assoc. 2000;131(2):211-6.

PMid:10680389

70. Lee SJ, McCall WD Jr., Kim YK, Chung SC, Chung JW. Effect of botulinum toxin injection on nocturnal bruxism: A randomized controlled trial. Am J Phys Med Rehabil. 2010;89(1):16-23. https://doi.org/10.1097/phm.0b013e3181bc0c78 PMid:19855255

71. Shim YJ, Lee MK, Kato T, Park HU, Heo K, Kim ST. Effects of botulinum toxin on jaw motor events during sleep in sleep bruxism patients: A polysomnographic evaluation. J Clin Sleep Med. 2014;10(3):291-8. https://doi.org/10.5664/jcsm.3532

\section{PMid:24634627}

72. Charles A. Perioperative Use of Botulinum Toxins. Abstracts Toxins. Toxicon. 2008;51:44. https://doi.org/10.1016/j. toxicon.2008.04.133

73. Ihde S. Prophylactic use of botulinum toxin in dental implantology. CMF Implement Dir. 2007;1:29-34.

74. Nayyar P, Kumar P, Nayyar PV, Singh A. BOTOX: Broadening the horizon of dentistry. J Clin Diagn Res. 2014;8(12):ZE25-9. PMid:25654058

75. Seok H, Park YT, Kim SG, Park YW. Correction of posttraumatic anterior open bite by injection of botulinum toxin Type A into the anterior belly of the digastric muscle: Case report. J Korean Assoc Oral Maxillofac Surg. 2013;39(4):188-92. https:// doi.org/10.5125/jkaoms.2013.39.4.188 PMid:24471041

76. Grünheid T, Langenbach GE, Korfage JA, Zentner A, van Eijden TM. The adaptive response of jaw muscles to varying functional demands. Eur J Orthod. 2009;31(6):596-612. https:// doi.org/10.1093/ejo/cjp093

PMid:19656804

77. Poulain B, Popoff MR, Molgó J. How do the botulinum neurotoxins block neurotransmitter release: From botulism to the molecular mechanism of action. Botulinum J. 2008;1(1):1487. https://doi.org/10.1504/tbj.2008.018951

78. Ting PT, Frieman A. The story of Clostridium botulinum: From food poisoning to Botox. Clin Med. 2004;4(3):258-61. PMid: 15244362

79. Naumann M, Albanese A, Heinen F, Molenaers G, Relja M. Safety and efficacy of botulinum toxin Type A following long-term use. Eur J Neurol. 2006;13:35-40. https://doi. org/10.1111/j.1468-1331.2006.01652.x PMid: 17112348

80. Sanjuan-Sanjuan A, Alamillos-Granados FJ, Dean-Ferrer A, de la Cruz ME, Mendez-García M, Murga-Oporto L. Electromyography assisted application of botulinum toxin in pterygoid musculature for the treatment of masticatory myofascial pain. Rev Esp Cirug Oral y Maxilofac. 2019;41(2):54-60. https://doi.org/10.20986/ recom.2019.1017/2018

81. Cote TR, Mohan AK, Polder JA, Walton MK, Braun MM Botulinum toxin Type A injections: Adverse events reported to the us food and drug administration in therapeutic and cosmetic cases. J Am Acad Dermatol. 2005;53:407-15. https://doi. org/10.1016/j.jaad.2005.06.011

PMid:16112345 